\title{
Model Pembelajaran Berbasis Saintifik Menggunakan Alat Peraga E Pen Interaktif dengan Muatan Kearifan Lokal pada Era Industri 4.0 untuk Pengajaran BIPA di Uninus
}

\author{
Rani Siti Fitriani \\ rani_sitifitriani@yahoo.com \\ Program Studi Pendidikan Bahasa dan Sastra Indonesia Universitas Islam Nusantara \\ Bandung, Indonesia
}

\begin{abstract}
Abstrak. Era revolusi industri 4.0 membawa perubahan dalam metode dan model pembelajaran BIPA. Salah satunya dengan model pembelajaran berbasis saintifik menggunakan alat peraga $e$ pen interaktif dengan muatan kearifan lokal untuk pengajaran. Model pembelajaran berbasis saintifik ini sesuai dengan kurikulum 2013 yang meliputi mengamati, menanya, mencoba, mengolah, menyajikan, menyimpulkan, dan mencipta. Berdasarkan hasil observasi, wawancara, dan tes (pretest dan postest), model dan alat peraga tersebut sangat membantu proses kegiatan belajar menyimak, berbicara, membaca, dan menulis untuk mahasiswa asing di Uninus. Pembelajar BIPA yaitu mahasiswa asing dapat belajar bahasa Indonesia sekaligus memahami bagaimana kearifan lokal Indonesia dari kekayaan budayanya seperti makanan, pakaian, rumah adat, alat musik, dan sebagainya dengan mudah, efektif, efesien, dan menyenangkan. Model pembelajaran berbasis saintifik menggunakan alat peraga $e$ pen interaktif dengan muatan kearifan lokal pada era industri 4.0 dapat meningkatan citra positif bahasa Indonesia dan kearifan lokal Indonesia bagi pembelajar BIPA.
\end{abstract}

Kata Kunci: model saintifik, e pen interaktif, BIPA, kearifan lokal

\section{Pendahuluan}

Pada era perkembangan industri 4.0 saat ini, beragam hal dilakukan untuk meningkatkan kualitas pendidikan dan tercapainya indikator pembelajaran dengan baik. Salah satunya adalah penggunaan model pembelajaran yang tepat, menarik, efektif, efesien, dan inovatif. Pengembangan alat peraga menjadi hal yang cukup penting untuk mendukung kegiatan pembelajaran BIPA . Tujuannya agar pembelajar yaitu mahasiswa asing lebih tertarik dan mudah memahami materi BIPA. Penulis sebagai Direktur BIPA Uninus, menggunakan model pembelajaran saintifik menggunakan alat peraga $e$ pen interkatif dengan muatan kearifan lokal dalam pengajaran BIPA untuk mahasiswa asing di Uninus.

Pengembangan model pembelajaran BIPA saat ini diperlukan, sesuai dengan perkembangan ilmu pengetahuan dan teknologi, kebutuhan pembelajar, dan pencapaian tujuan pembelajaran BIPA. Menteri Pendidikan dan Kebudayaan (Mendikbud) Muhadjir Effendy menilai aspek pendidikan Indonesia perlu merevisi kurikulum dengan menambahkan lima kompetensi yang dimiliki oleh peserta didik. Kelima kompetensi itu dianggap sebagai modal yang sangat dibutuhkan untuk mampu bersaing dalam era revolusi industri 4.0. Lima kompetensi tersebut adalah:

Rani Siti Fitriani | Model Pembelajaran Berbasis Saintifik Menggunakan Alat Peraga E Pen Interaktif dengan Muatan 
1. kemampuan berpikir kritis;

2. memiliki kreatifitas dan kemampuan yang inovatif;

3. kemampuan dan keterampilan berkomunikasi yang baik;

4. kemampuan kerjasama; dan

5. memiliki kepercayaan diri yang tinggi.

\section{(Republika.co.ic)}

Pengajaran BIPA dengan muatan nilai kearifan lokal budaya nusantara berdampak pada orang asing untuk belajar budaya baru sehingga mengembangkan kompetensi berbahasanya. Pengajaran BIPA berdampak pada citra positif masyarakat Indonesia yang ramah, santun, rendah hati, penyayang, dan peduli dengan kelestarian dan keseimbangan alam. Salah satu aspek penting yang tak terpisahkan dari budaya adalah kearifan lokal. Kearifan lokal merupakan suatu identitas/kepribadian budaya bangsa yang menyebabkan bangsa tersebut mampu menyerap dan mengolah kebudayaan asing sesuai watak dan kemampuan sendiri (Soebadio dalam Ayatrohaedi, 1986: 18-19).

Pengajaran BIPA yang menarik dengan muatan kearifan lokal pada era globalisasi saat ini menjadi salah satu pengajaran bahasa yang sangat penting dilakukan untuk memudahkan komunikasi yang efektif bagi mahasiswa asing yang belajar BIPA tidak hanya untuk di dalam negeri tapi juga di luar negeri. Pengajaran BIPA tidak dapat disamakan dengan pengajaran bahasa Indonesia bagi penutur bahasa Indonesia karena pembelajar BIPA memiliki latar budaya yang berbeda dengan budaya Indonesia. Hal tersebut menjadikan pengajaran BIPA memiliki kekhusuan dalam hal aspek pengajaran, seperti pengajar, pembelajar, kurikulum, metode, dan bahan ajar, serta aspek lain yang harus disesuaikan dengan kebutuhan pembelajar.

Mengapa pengajaran BIPA tidak dapat dilepaskan dengan nilai-nilai budaya yakni kearifan lokal? Alasannya karena muatan kearifan lokal dalam pengajaran BIPA dapat memotivasi pembelajar untuk memahami budaya semakin tinggi. Semakin tinggi pemahaman budaya pembelajar maka semakin tinggi juga tingkat toleransi dan tingkat kepekaan pembelajar dalam menggunakan keterampilan bahasa. Menurut Quaritzch Wales kearifan lokal merupakan kumpulan ciri budaya dari mayoritas masyarakat sebagai hasil dari pengalaman hidup mereka (Rahyono 2009:7). Pengertian itu menyangkut (1) ciri budaya, (2) sekelompok manusia sebagai pemilik budaya, dan (3) pengalaman hidup yang menghasilkan ciri budaya. Menurut Rahyono (2009: 9), pembelajaran kearifan lokal mempunyai posisi yang strategis. Posisi strategis itu, antara lain (1) kearifan lokal salah satu pembentuk identitas, (2) kearifan lokal bukan merupakan sebuah nilai yang asing bagi pemiliknya, (3) keterlibatan emosional masyarakat dalam penghayatan kearifan lokal kuat, (4) kearifan lokal mampu menumbuhkan harga diri, dan (5) kearifan lokal mampu meningkatkan martabat bangsa dan negara.

Ada sejumlah tujuan penggunaan kearifan lokal dalam pembelajaran BIPA. Telah diketahui bersama bahwa Indonesia sangat kaya akan budaya. Setiap budaya di Indonesia memiliki kearifan lokal sesuai dengan kondisi masyarakat tersebut berkembang. Saat ini belum dilakukan inventarisasi secara maksimal terhadap kearifan lokal. Salah satu tujuan pembuatan bahan ajar berbasis kearifan lokal adalah membantu pemangku kepentingan

Rani Siti Fitriani | Model Pembelajaran Berbasis Saintifik Menggunakan Alat Peraga E Pen Interaktif dengan Muatan 
dalam melakukan inventarisasi kearifan lokal. Semakin banyak dan beragam bahan ajar yang berbasis kearifan lokal semakin tinggi sumbangsihnya dalam membantu pemangku kepentingan dalam inventarisasi kearifan lokal yang ada.

Kearifan lokal berhubungan erat dengan bahasa dan budaya nusantara. Setiap budaya dapat diamati melalui karakter bangsa. Bahasa dan budaya ibarat mata uang logam yang memiliki dua sisi bersifat dwimuka, ditinjau dari segi bahasa sebagai alat budaya dan bahasa sebagai bagian dari budaya. Pengajaran BIPA adalah pengajaran yang khas dan khusus karena masyarakat yang belajar bahasa Indonesia adalah mahasiswa asing. Kearifan lokal terdapat dalam semua aspek kehidupan budaya nusantara. Kekayaan dan keberagaman kearifan lokal inilah yang dapat dikembangkan sebagai materi bahan ajar BIPA. Unesco sangat mendukung pembelajaran yang menyebarluaskan kearifan lokal kepada masyarakat dunia yang dapat digunakan sebagai solusi alternatif dalam menangani permasalahan kehidupan. Untuk itu, kearifan lokal budaya perlu diangkat, didokumentasikan, dilestarikan, dan direvitalisasi.

\section{Hasil dan Pembahasan \\ Model Pembelajaran Stantifik Menggunakan E Pen Interaktif dengan Muatan Kearifan Lokal}

Pembelajaran merupakan proses seseorang untuk memperoleh atau mendapatkan ilmu pengetahuan atau keterampilan tentang suatu subjek yang dipelajari berdasarkan hasil pengalaman, diskusi, latihan, pengamatan, bacaan, dan sebagainya yang dilakukan secara terarah dan berkesinambungan. Gunter et al (1990: 67) mendefinisikan bahwa model pembelajaran adalah "an instructional model is a step-by-step procedure that leads to specific learning outcomes" "Model pembelajaran adalah prosedur yang berupa langkahdemi-langkah yang mengarah pada hasil belajar yang spesifik'. Menurut Rusman (2011, 132-133) model pembelajaran biasanya disusun berdasarkan berbagai prinsip atau teori pengetahuan, sehingga meminjam pendapat Joyce dan Weil, Rusman menyatakan bahwa model pembelajaran adalah suatu rencana atau pola yang dapat digunakan untuk membentuk kurikulum (rencana pembelajaran jangka panjang), merancang bahan-bahan pelajaran, artinya pengajar boleh memilih model pembelajaran yang sesuai dan efisien untuk mencapai tujuan pendidikannya.

Ada tiga hal yang memengaruhi tercapainya tujuan pengajaran BIPA yaitu, karakteristik pembelajar, materi pembelajaran, dan pembelajaran.

\section{Karakteristik pembelajar}

Latar budaya, kemampuan bahasa Indoensia, profesi, pendidikan, dan bahasa ibu memengaruhi karakteristik dari pembelajar BIPA. Hal tersebut akan berkaitan erat dengan model atau metode apa yang tepat untuk digunakan dalam pengajaran BIPA bagi pembelajar BIPA.

2. Materi pembelajaran

Materi pembelajaran BIPA harus sesuai dengan kurikulum program BIPA. Prinsipprisnsip yang dijadikan dalam menentukan materi pembelajaran BIPA adalah,

a) Relevansi (kesesuaian) 
Materi pembelajaran harus relevan dengan tujuan pencapaian standar kompetensi dan kompetensi dasar; perkembangan zaman saat ini; kebutuhan pembelajar saat in; dan sebagainya. Oleh karena itu, materi pembelajaran harus sesuai dengan fakta atau fenomena yang ada.

b) Konsistensi (Keajegan)

Materi pembelajaran harus konsisten dengan kurikulum dan tujuan pencapaian standar kompetensi dan kompetensi dasar. Dengan demikian, materi yang konsinten dapat membantu mencapai indikator tujuan pembelajaran BIPA.

c) Efektif \& Efesien

Materi pembelajaran BIPA harus diberikan dengan efektif dan efesian untuk memudahkan pembelajar memahami materi yang dijelaskan atau diajarkan oleh pengajar atau guru. Hal tersebut akab berpengaruh pada idikator tujuan pembelajaran BIPA. Materi yang bertele-tele atau tidak efektif dan tidak efesien akan membuat pembelajar merasa jenuh, bosa, dan tidak tertarik atau tidak semangat untuk belajar. Pengaturan alokasi waktu sangat penting untuk diperhatikan dalam setiap pertemuan.

d) Menarik dan inovatif

Untuk mendukung materi BIPA, diperlukan alat peraga yang menarik dan inovatif sehingga dapat membantu pencapaian indikator tujuan pembelajaran. Pengembangan alat peraga pengajaran BIPA pada era industri 4.0 menjadi hal yang harus dilakukan sehingga materi pengajaran BIPA semakin mudah dipahami oleh pembelajar dengan baikdan cepat.

3. Pembelajaran

Pembelajaran merupakam proses, cara, perbuatan, menjadikan seseorang belajar. Ciri-ciri pembelajaran menurut Sugandi, dkk (2000:25) adalah

a) pembelajaran dilakukan secara sadar dan direncanakan secara sistematis;

b) pembelajaran dapat menumbuhkan perhatian dan motivasi siswa dalam belajar;

c) pembelajaran dapat menyediakan bahan belajar yang menarik dan menantang bagi siswa;

d) pembelajaran dapat menggunakan alat bantu belajar yang tepat dan menarik;

e) pembelajaran dapat menciptakan suasana belajar yang aman dan menyenangkan bagi siswa; dan

f) pembelajaran dapat membuat siswa siap menerima pelajaran baik secara fisik maupun

psikologis.

Pembuatan model pembelajaran BIPA dengan menggunakan alat peraga pengajaran BIPA perlu dilakukan karena dapat memberikan kesempatan bagi pembelajar untuk mempraktikan kaidah-kaidah bahasa sehingga pembelajar dapat menyadari sejauh mana pencapaian pembelajarannya; memberikan kesempatan bagi pembelajar untuk berani berkomunikasi dalam suasana yang nyaman dan alami; memberikan kesempatan bagi pembelajar untuk meningkatkan kelancaran berbahasanya; dan 4) memberikan kesempatan bagi pembelajar untuk mendapat informasi yang faktual sesuai dengan kebutuhan belajar.

Rani Siti Fitriani | Model Pembelajaran Berbasis Saintifik Menggunakan Alat Peraga E Pen Interaktif dengan Muatan 
Model pembelajaran saintifik merupakan pendekatan yang berpusat kepada siswa Majid (2014: 211) menyebutkan bahwa pendekatan saintifik dalam pembelajaran meliputi mengamati, menanya, mencoba, mengolah, menyajikan, menyimpulkan, dan mencipta. Langkah-langkah model pendekatan saintifik pada pembelajaran kurikulum 2013 adalah mengamati, menanya, mencoba, mengasosiasikan, dan mengkomunikasikan.

1. Mengamati

Metode memngamati mengutamakan kebermaknaan proses Mengamati sangat bermanfaat bagi pemenuhan rasa ingin tahu peserta didik. Oleh karena itu, proses pembelajaran memiliki kebermaknaan yang tinggi. Pendekatan model stantifik metode mengamati, siswa menemukan fakta bahwa ada hubungan antara obyek yang dianalisis dengan materi pembelajaran yang digunakan oleh guru. Saat guru menjelasakan tentang rumah adat dengan menggunakan e pen maka siswa akan mengamati dan menyimaknya. Misalnya, bahan yang digunakan untuk rumah adat tersebut, makna dari arsitektur rumah adat (seperti jumlah tiang, jumlah anak tangga, model atap, dsb), gambar atau hiasan rumah adat, dan sebagainya. Tentunya tidak semua penjelasan dapat dipahami oleh siswa karena mungkin masing asing didengar atau baru didenganrnya.

2. Menanya

Setelah siswa mengamati atau menyimak penjelasan guru mengunakan $e$ pen interaktif selanjutnya siswa dipersilakan untuk bertanya. Metodesaintifikmenyebutnya dengan tahapan/langkah menanya. Menanya artinya mengajukan pertanyaan tentang hal-hal yang tidak dipahami dari apa yang diamati oleh siswa. Jadi, setelah atau pertanyaan untuk mendapatkan informasi tambahan tentang apa yang diamati. Membuat dan mengajukan pertanyaan, tanya jawab, berdiskusi tentang informasi yang belum dipahami, informasi tambahan yang ingin diketahui, atau sebagai klarifikasi. Misalnya, siswa menanyakan kepada guru mengapa rumah adat di Pulau Sumatera dibangun dengan bentuk panggung yang tinggi? Siswa akan antusias bertanya beragam hal yang belum dipahami dari penjelasan rumah adat tersebut kepada guru.

3. Mencoba

Langkah model pembelajaransaintifikselanjutnya dalah mencoba. Mencoba artinya melakukan eksperimen, membaca sumber lain selain buku teks, mengumpulkan data dari narasumber melalui angket, wawancara. Pada tahap ini, siswa dapat mencari sumber referensi lainnya untuk dapat mengetahui lebih banyak mengenai materi yang belum dipahami. Misalnya, setelah mendengar penjelasan guru tentang alasan mengapa rumah adat di daerah Sumatera berbentuk panggung yang tinggi maka siswa pun mencari referesni lainnya baik di buku atau di internet.

4. Mengasosiasikan

Setelah siswa mencoba mencari informasi atau sumber referensi lainnya mengenai hal yang ingin diketahui maka selanjutnya menurut metode staintifik, siswa akan mengasosiasikan. Mengasosiasikan berarti mengolah informasi yang sudah dikumpulkan, menganalisis data dalam bentuk membuat kategori, mengasosiasi atau menghubungkan fenomena/informasi yang terkait dalam rangka menemukan suatu pola, dan menyimpulkan. Siswa akan menghubungkan informasi yang ia peroleh dari penjelasan $e$

Rani Siti Fitriani | Model Pembelajaran Berbasis Saintifik Menggunakan Alat Peraga E Pen Interaktif dengan Muatan 
pen interaktif, penjelasan guru, dan bacaan atau video yang ia simak. Hal tersebut dapat memotivasi siswa untuk aktif juga berpikir kritis dan kreatif.

5. Mengkomunikasikan

Setelah langkah-langkah metodesaintifikdi atas terlaksana, selanjutnya siswa akan diminta untuk menyajikan apa yang ia peroleh dari menyimak penjelaan dari e pen, penjelasan dari guru, penjelasan dari sumber refernesi (buku dan internet), berupa tulisan yang ia bacakan di depan kelas. Dengan demikian, siswa dapat menunjukkan kemampuan berbahasa Indonesia pada tahap mengkomunikasikan ini. Siswa yang lain dapat menyimak penjelasan siswa tersebut. Tahap mengkomunikasikan dalam modelsaintifikartinya menyajikan laporan dalam bentuk bagan, diagram, atau grafik; menyusun laporan tertulis; dan menyajikan laporan meliputi proses, hasil, dan simpulan secara lisan.

Sebelum kegiatan belajar dimulai, penulis membagikan tes awal kepada siswa mengani materi yang akan diberikan pada pertemuan tersebut. Bentuk pertanyaanya berupa isian dengan jawabnnya yang singkat. Setelah itu guru menjelasakan materi dengan model pendekatan model pembelajaran berbasissaintifik menggunakan alat peraga $e$ pen interaktif dengan muatan kearifan lokal seperti yang telah dideskripsikan tahapannya. Setelah semua langkah model saintifik dilakukan, selanjutnya guru memberikan tes akhir untuk siswa dengan isi pertanyaan yang sama dengan tes awal.

\section{Simpulan}

Berdasarkan pembelajaran dengan model pendekatan berbasis saintifik mengunakan alat peraga $e$ pen interaktif dengan muatan kearifan lokal maka dapat disimpulkan bahwa model pembelajaran saintifik sangat efektif, efesien, dan menarik untuk pengajaran BIPA. Penggunaan alat $e$ pen interaktif dengan muatan kearifan lokal akan menciptakan kegiatan belajar yang menarik dan inovatif juga memotivasi siswa untuk mencari tahu lebih banyak tetang materi yang dipelajari. Dengan demikian, pada era indutrsi 4.0, model pendekatan saintifik dengan alat peraga interaktif bermuatan kearifan lokal dapat dijadikan model pembelajaran yang dapat diterapkan dalam pengajaran BIPA baik di dalam maupun di luar negeri

\section{Daftar Pustaka}

Ayatrohaedi. (1986). Kepribadian Budaya bangsa (Local Genius). Jakarta: Pustaka Pelajar.

Dardjowidjojo, S. (1996). Metode dan keberhasilan Pengajaran Bahasa. Makalah dalam Konferensi Internasioanl II Pengajaran Bahasa Indonesia bagi Penutur Asing (KIPBIPA II). IKIP PADANG.

Dubin, F, and D.E Eskey and W Grabe. (1986). Teaching Second Language: Reading for Academic Purposes. Addison: Wesley Publishing Co.

Kartomihardjo, S. (1996). Bahan Pengajaran Bagi Pembelajar Pemula dan Teknik Penyampaiannya. Makalah dalam Konferensi Internasional II Pengajaran Bahasa Indonesia Bagi Penutur Asing (KIPBIPA II). IKIP Padang

Rani Siti Fitriani | Model Pembelajaran Berbasis Saintifik Menggunakan Alat Peraga E Pen Interaktif dengan Muatan Kearifan Lokal pada Era Industri 4.0 untuk Pengajaran BIPA di Uninus | 
Lapoliwa, H. (1996). BIPA dan Pembinaan Citra Bahasa Indonesia. Makalah dalam Konferensi Internasioanl II Pengajaran Bahasa Indonesia bagi Penutur Asing (KIPBIPA II). IKIP PADANG.

Nunan, D. (1990). Designing Tasks for Communicative Classroom. Cambridge: Cambridge University Press.

Fitriani, Rani Siti. (2017). Pengajaran BIPA dengan Muatan Kearifan Lokal Budaya Sunda untuk Mahasiswa Asing di FKIP Uninus 'Teaching and Learning BIPA with Sundanese Valuesfor Foreign Students in FKIP Uninus'. Konferensi Internasional Pengajara BIPA X Malang, Unit Pengembangan Bahasa Universitas Brawijaya, Afliansi Pengajar Penggiat BIPA (APPBIPA) Pusat, \& Pusat Pengembangan Strategi dan Diplomasi Kebahasaan Badan Pengembangan dan Pembinaan Bahasa Kementrian Pendidikan dan Kebudayaan

--- (2015). Potensi Program BIPA di Perguruan Tinggi dan Tantangan Menghadapi Ekonomi ASEAN. Seminar Nasional Meningkatkan Kompetensi Guru yang Mandiri dalam Menyongsong Ekonomi ASEAN, Asosiasi Pengajar Bahasa Indonesia dan PBS Indonesia FKIP Uninus

Gunter, M.A., Estes, T.H., \& Schwab, J.H. (1990). Instruction: A Models Approach. Boston: Allyn and Bacon.

Rahyono, F.X. (2012). Kearifan Budaya dalam Kata. Jakarta: Wedatama Widya Sastra.

Riasa, N. 1996. Bahasa In Bali: Program Pengajaran Bahasa Indonesia yang Memadukan Komponen Linguistik dan Budaya Bagi Penutur Asing. Makalah dalam Konferensi Internasioanl II Pengajaran Bahasa Indonesia bagi Penutur Asing (KIPBIPA II). IKIP PADANG.

Rusman. (20110. Model-Model Pembelajaran. Bandung: Rajawali Press.

Subyakto, N. (1996). Pengajaran Bahasa Indonesia Kepada Penutur Asing Menurut Pendekatan Komunikatif. Makalah dalam Konferensi Internasioanl II Pengajaran Bahasa Indonesia bagi Penutur Asing (KIPBIPA II). IKIP PADANG.

Sugandi, A. (2000). Teori Pembelajaran. Bandung: PT. Remaja Rosdakarya. 